Check for updates

Cite this: RSC Adv., 2019, 9, 22240

Received 16th May 2019

Accepted 5th July 2019

DOI: $10.1039 / c 9 r a 03690 c$

rsc.li/rsc-advances

\title{
Improving the anticancer activity of platinum(Iv) prodrugs using a dual-targeting strategy with a dichloroacetate axial ligand $\dagger$
}

\begin{abstract}
Fengfan Liu, ${ }^{a}$ Xiaomei Dong, ${ }^{a}$ Qiwen Shi, ${ }^{a}$ Jianli Chen ${ }^{\text {a }}$ and Weike Su (D) *ab
Four novel platinum(Iv) complexes, characteristic of DCA/TFA and with chloride ions as axial ligands, were designed and synthesized. This type of platinum(Iv) complexes $1 \mathrm{a}-2 \mathrm{~b}$ exhibited significant cytotoxic activity, and the cytotoxicity of $1 \mathrm{~b}$ was the greatest among these four complexes, which was 20.61 fold and 7.65 fold higher than that of cisplatin against HepG-2 and $\mathrm{NCl}-\mathrm{H} 460$ cancer cells, respectively. The result from the apoptosis assay of $1 \mathrm{~b}$ was consistent with the result from the cytotoxicity assay. In addition, complexes $1 \mathrm{a}$ and $1 \mathrm{~b}$ induced cell cycle arrest at the S phase on HepG-2 cells. Taken together, our data showed that Pt(IV) complex $1 \mathrm{~b}$ released the corresponding $\mathrm{Pt}(॥)$ complex and DCA, and induced apoptosis as well as disruption of the mitochondrial membrane potential, establishing $\mathrm{Pt}(\mathrm{IV})$ complex $1 \mathrm{~b}$ as a potential dual-targeting anticancer agent.
\end{abstract}

\section{Introduction}

The United States Food and Drug Administration (FDA) has approved cisplatin, carboplatin, and oxaliplatin for the treatment of cancer. ${ }^{1,2}$ According to previous reports, platinum drugs were administered to $50-70 \%$ of cancer patients, either as single drugs or in combination with other drugs. ${ }^{3}$ However, side effects and drug resistance have greatly limited the therapeutic application of platinum drugs..$^{3-6}$ Therefore, a variety of functional platinum complexes with different strategies have been studied to improve cancer therapy, including receptor targeting of platinum complexes, nano-delivery of platinum complexes and dual-threat platinum prodrugs..$^{7-12}$ In addition, the FDA has approved an immunotherapy for patients with a specific type of lung cancer in 2018, which needs adjuvant treatment with platinum-containing chemotherapy. ${ }^{13,14}$ Therefore, through a process of continuous design for improvement, these drugs will still play an important role in the future. ${ }^{15-18}$ In our previous research, complexes $\mathbf{A}$ and $\mathbf{B}$ exhibited similar activity compared with cisplatin and oxaliplatin, but their toxicity against normal cells was lower than that of cisplatin and oxaliplatin. ${ }^{1920}$ The results indicated that both of them were promising anticancer lead compounds for further study (Fig. 1).

${ }^{a}$ National Engineering Research Center for Process Decelopment of Active Pharmaceutial Ingredients, Collaborative Innovation Center of Yangtze River Delta Region Green Pharmaceuticals, Zhejiang University of Technology, Hangzhou, P. R. China. E-mail: pharmlab@zjut.edu.cn

${ }^{b}$ College of Pharmaceutical Sciences, Zhejiang University of Technology, Hangzhou, P. R. China

$\dagger$ Electronic supplementary information (ESI) available. See DOI: 10.1039/c9ra03690c
Dichloroacetate (DCA), an enzyme pyruvate dehydrogenase kinase inhibitor, can reverse the Warburg effect by improving the way pyruvate enters mitochondria. ${ }^{21}$ It can reduce tumor cell proliferation and promote cancer cell death via inducing apoptosis and mitochondrial dysfunction. In fact, $\mathrm{Pt}(\mathrm{II}) /(\mathrm{Iv})$ complexes could effectively increase the anticancer activity by introducing one or two DCA into the axial ligands (Fig. 1).22-24 On the other hand, taking the trifluoroacetate (TFA) group as the ligand can increase the lipophilicity and possess good ability to be dissociated. ${ }^{25,26}$ Therefore, we designed and synthesized Pt(Iv) complexes $\mathbf{2 a}$ and $\mathbf{2 b}$ with TFA as the axial ligand.

Since platinum(Iv) prodrugs have kinetic inertia and contain functional groups in the axial position, their characteristics include minimizing unwanted side reactions with biomolecules prior to activation of $\mathrm{Pt}(\mathrm{Iv})$ prodrugs, enhancing the cytotoxicity of platinum complexes, regulating the reduction rate and altering the lipophilicity of resulting complexes. The bioactive molecule can ultimately combine with platinum(II) complex

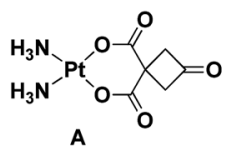

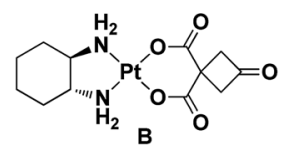
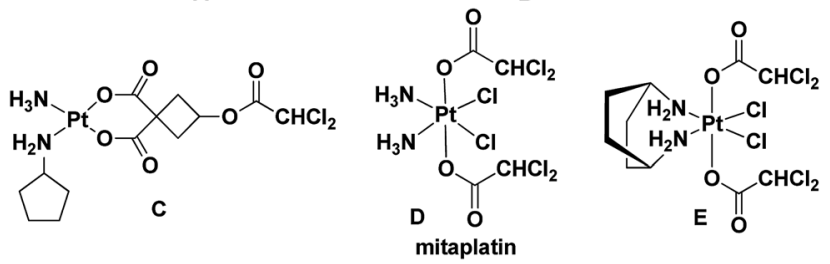

Fig. 1 Leading compounds ( $\mathrm{A}$ and $\mathrm{B}$ ) and known platinum complexes of ligands with dichloroacetate (C-E). 
dissociated from the platinum(Iv) prodrug under the reductive condition to improve anti-tumor effects. Until now, cisplatinbased and oxaliplatin-based $\mathrm{Pt}(\mathrm{Iv})$ complexes have been used to act as leading compounds. Herein, we designed and synthesized four novel Pt(Iv) complexes 1a-2b with a new structure to reduce side effects prior to activation of $\mathrm{Pt}(\mathrm{Iv})$ prodrugs and target nuclear DNA and mitochondria (Scheme 1). This work was motivated idea from Mitaplatin analogue, which firstly displayed a dual-targeting strategy with dichloroacetate axial ligand. ${ }^{22}$

\section{Results and discussion}

\subsection{Chemistry}

Notably, Pt(Iv) complexes 1a-2b were synthesized by the oxidative chlorination of the corresponding platinum(II) complexes A and $\mathbf{B}$ with $N$-chlorosuccinimide in the acetone solution of dichloroacetic acid or trifluoroacetic acid, respectively. This procedure obtained $\mathrm{Pt}$ (Iv) complexes adopting a one-pot synthesis (Scheme 1). All complexes were characterized by using IR, ${ }^{1} \mathrm{H}$ NMR, ${ }^{13} \mathrm{C}$ NMR and ESI-MS and elemental analysis. $\mathrm{N}-\mathrm{H}$ stretching vibrations were found in the IR spectra of the platinum complexes ranging from $3061-3574 \mathrm{~cm}^{-1}$. The coordination of the amino group to platinum(II) caused the difference between the vibrations. The presence of stretches between 2936 and $2939 \mathrm{~cm}^{-1}$ confirmed the presence of C-H bonds. In the ${ }^{1} \mathrm{H}$ NMR spectra, the cyclobutyl proton of complexes $\mathbf{A}$ and $\mathbf{B}$ appeared at a single peak in $3.71 \mathrm{ppm}$. These signals were completely different from those of the corresponding platinum(Iv) complexes 1a-2b appearing the split by the introduction ligands into the axial position. The $\mathrm{CHCl}_{2}$ signal of the complexes 1a and $1 \mathrm{~b}$ appeared at a single peak in $6.52 \mathrm{ppm}$ and $6.49 \mathrm{ppm}$, respectively. In the ${ }^{13} \mathrm{C}$ NMR spectrum, the peaks at $\delta$ 67.1, 67.7 assignable to $\mathrm{CHCl}_{2}$ carbon, at $\delta(62.4,58.6), \delta(62.6$, 58.3) for $\mathrm{C}-\mathrm{N}$ carbons (1b and $\mathbf{2 b}$ ), respectively. The ESI-MS showed $[\mathrm{M}+\mathrm{Na}]^{+}$peaks that were in agreement with the proposed molecular formulas of the metal complexes.

\subsection{Stability of complexes $1 \mathrm{a}-2 \mathrm{~b}$ in PBS}

The stability of complexes $\mathbf{1 a}$ and $\mathbf{1 b}$ in a solution of deuterated aqueous and phosphate buffered solution (PBS 7.87 mM, pH 7.4

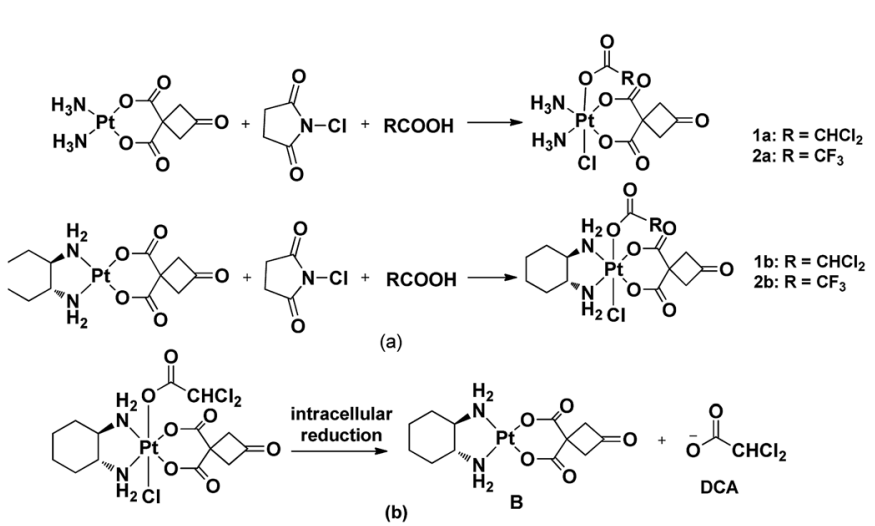

Scheme 1 (a) Synthetic route of target complexes 1a-2b; (b) proposed mechanism of activation of $1 \mathrm{~b}$. in DMSO- $d_{6} / \mathrm{D}_{2} \mathrm{O}$ ratio of $\left.10: 90(\mathrm{v} / \mathrm{v})\right)$ at $37^{\circ} \mathrm{C}$ was investigated by ${ }^{1} \mathrm{H}$ NMR technique at different time. As shown in Fig. 2, the peak of coordinated DCA in complex 1a located at $6.18 \mathrm{ppm}$. After 50 minutes incubation under the physiological condition, we observed the decay of the $\mathrm{CHCl}_{2}$ signal at $6.18 \mathrm{ppm}$ (marked with $\Delta$ in Fig. 2) and the concomitant increase of a signal resonating at $5.86 \mathrm{ppm}$ ( indicates the peak of free DCA). The half-life of 1a was approximately 50 minutes, which had a value quite similar to that reported for kiteplatin $(60 \mathrm{~min}){ }^{20}$ Meanwhile, $\mathbf{1 b}$ (60 $\mathrm{min}$ ) has the same half-life as $\mathbf{1 a}$ and kiteplatin in the same experimental conditions. As shown in Fig. S32 and $\mathrm{S} 33, \uparrow$ the half-lives of complexes $\mathbf{1 a}$ and $\mathbf{1 b}$ were similar to those obtained by ${ }^{1} \mathrm{H}$ NMR. On the other hand, the characteristic peaks of complexes $\mathbf{2 a}$ and $\mathbf{2 b}$ are not so obvious in ${ }^{1} \mathrm{H}$ NMR. The stability of $\mathbf{2 a}$ and $\mathbf{2 b}$ in the solution of $\mathrm{MeOH} / \mathrm{PBS}(\mathrm{v} / \mathrm{v}=$ $1: 9)$ was examined by HPLC at different times. As shown in Fig. S34 and S35† (ESI $\dagger$ ), the half-life of $2 \mathbf{a}$ and $\mathbf{2 b}$ was approximately 50-60 minutes under the physiological condition, which were lower than that found for $c t-\left[\mathrm{Pt}\left(\mathrm{NH}_{3}\right)_{2}(-\right.$ TFA $)_{2}$ (CBCDA)] (5) with TFA as axial ligands (PBS, $37^{\circ} \mathrm{C}, \mathrm{pH} 7.0$, $\left.t_{1 / 2}=142 \mathrm{~min}\right){ }^{27}$ Furthermore, the complexes 1a-2b were stable in methanol for 48 hours (S36-S39†).

\subsection{In vitro cytotoxicity assay}

The cytotoxicity of complexes $\mathbf{1 a - 2 b}$ was first tested in vitro by MTT assay in BGC803, HepG-2, MCF-7 and NCI-H460 cancer cell lines with cisplatin, oxaliplatin, and carboplatin as positive controls. The $\mathrm{IC}_{50}$ values of them were reported in Table 1.

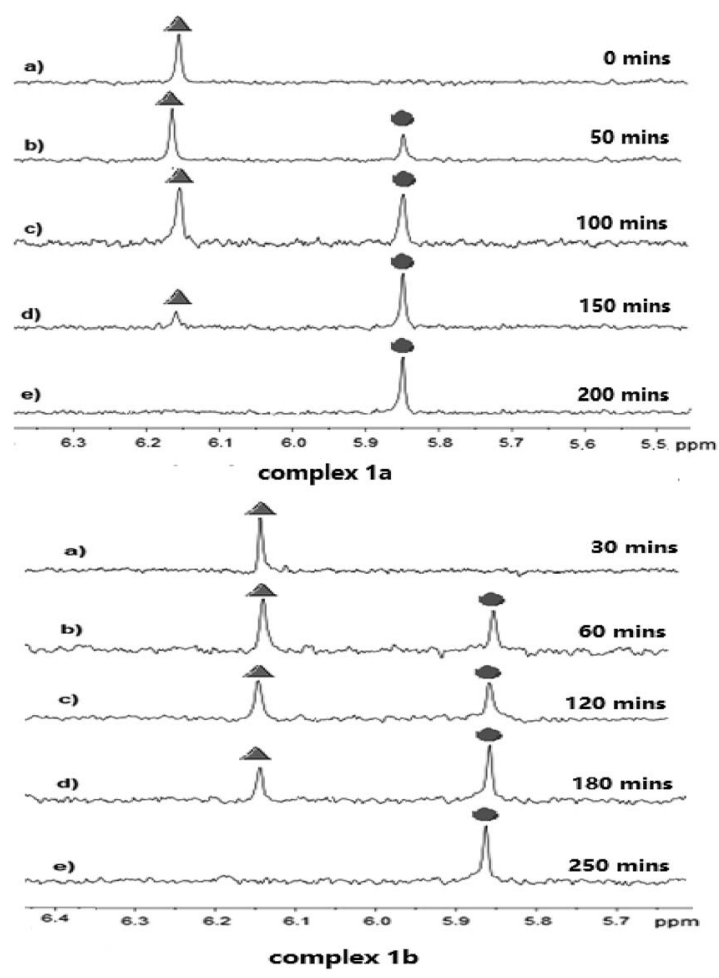

Fig. 2 Portion of the ${ }^{1} \mathrm{H}$ NMR $(400 \mathrm{MHz})$ spectra of complexes $1 \mathrm{a}$ and $1 \mathrm{~b}$ in deuterated aqueous and phosphate buffered solution (PBS $7.87 \mathrm{mM}, \mathrm{pH}$ 7.4 ; at $\left.37^{\circ} \mathrm{C} ; 10 \% \mathrm{v} / \mathrm{v} \mathrm{DMSO}-d_{6}\right)$. $\triangle$ indicates the peak of coordinated DCA in complex $1 \mathrm{a}$ and $1 \mathrm{~b}$. indicates the peak of free DCA. 
Table 1 In vitro cytotoxicity of complexes $1 \mathrm{a}-2 \mathrm{~b}$, cisplatin, carboplatin and oxaliplatin

\begin{tabular}{|c|c|c|c|c|}
\hline Complex & \multicolumn{4}{|l|}{$\mathrm{IC}_{50}{ }^{a}(\mu \mathrm{M})$} \\
\hline Oxaliplatin & $29.10 \pm 1.65$ & $26.49 \pm 2.55$ & $41.27 \pm 3.43$ & $13.43 \pm 1.13$ \\
\hline Carboplatin & $77.14 \pm 5.35$ & $42.32 \pm 2.55$ & $179.40 \pm 10.56$ & $52.93 \pm 4.98$ \\
\hline DCA & $>100$ & $>100$ & $>100$ & $>100$ \\
\hline $1 \mathrm{a}$ & $57.73 \pm 4.34$ & $10.36 \pm 1.24$ & $27.08 \pm 2.25$ & $>200$ \\
\hline $1 b$ & $7.63 \pm 0.56$ & $1.35 \pm 0.15$ & $7.96 \pm 0.76$ & $1.94 \pm 0.13$ \\
\hline $2 \mathbf{a}$ & $14.09 \pm 0.98$ & $15.00 \pm 1.42$ & $22.63 \pm 2.05$ & $5.46 \pm 0.43$ \\
\hline $2 \mathbf{b}$ & $15.01 \pm 1.05$ & $17.54 \pm 1.65$ & $22.20 \pm 2.17$ & $7.66 \pm 0.57$ \\
\hline
\end{tabular}

These four complexes displayed potent antitumor activity against BGC803, HepG-2, MCF7 and NCI-H460 cancer cell lines with the $\mathrm{IC}_{50}$ values in the range of 7.63-57.73 $\mu \mathrm{M}, 1.35-17.54$ $\mu \mathrm{M}, 7.96-27.08 \mu \mathrm{M}$ and $1.94-200 \mu \mathrm{M}$, respectively. Among them, complex 1b showed the highest activity against four cancer cell lines, which was superior to positive controls (cisplatin, oxaliplatin and carboplatin). DCA had no obvious cytotoxic activity on cancer cell lines with the $\mathrm{IC}_{50}$ values exceeding $100 \mu \mathrm{M}$. It was noted that $\mathbf{1 b}$ exhibited higher cytotoxic activity than an equivalent mixture: DCA : $\mathbf{A}(1: 1)$ and DCA : B (1:1), implying that the special structure of complex $\mathbf{1 b}$ resulted in better cytotoxic activity. Notably, complex 1b exhibited 20.61 fold and 7.65 fold higher cytotoxicity toward HepG-2 and NCI-H460 cancer cells than that of cisplatin. Meanwhile, the cytotoxic activity of complex $\mathbf{1 b}$ was 2.82 fold and 3.66 fold more potent than that of cisplatin against BGC803 and MCF-7, respectively.

By the analysis of the structure-activity relationship and cytotoxic activity, the design of novel Pt(Iv) $\mathbf{1 a}$ and $\mathbf{1} \mathbf{b}$ effectively improved the anti-tumor activity. Moreover, taking this type of complexes as prodrugs could reduce the attack of small sulfurcontaining molecules (e.g., glutathione, methionine and metallothionein) and maintain a relatively stable structure before reaching tumor cells. After that, complexes $\mathbf{1 a}$ and $\mathbf{1 b}$ could release $\mathbf{B}$ and DCA, playing a dual-targeting anti-tumor effect against cancer cells, targeting nuclear DNA and mitochondria, respectively. In addition, complexes $\mathbf{2 a}$ and $\mathbf{2 b}$ exhibited good effects against BGC803, HepG-2, MCF-7 and NCI-H460 cancer cell lines, demonstrating that the axial ligand can be modified to alter the reductive rate and the lipophilicity of $\mathrm{Pt}$ (Iv) complexes and consequently enhance the anti-tumor activity of Pt(Iv) complexes.

Based on the above results, complexes 1a-2b were selected for further investigation against SGC7901, SGC7901/CDDP and HUVEC cells lines by MTT assay. As shown in Table 2, complexes $\mathbf{1 a}$ and $\mathbf{1 b}$ showed the same cytotoxicity as oxaliplatin against SGC7901. However, SGC7901/CDDP cell line was not sensitive to all the tested compounds, indicating that these compounds were not able to overcome cisplatin resistance. In
HUVEC, the cytotoxicity of complexes $\mathbf{1 a}$ and $\mathbf{1 b}\left(\mathrm{IC}_{50}=59.11\right.$ $\mu \mathrm{M}$ and $\left.\mathrm{IC}_{50}=56.92 \mu \mathrm{M}\right)$ was lower than that of cisplatin $\left(\mathrm{IC}_{50}=\right.$ $36.92 \mu \mathrm{M})$. Meanwhile, neither compounds 2 a nor $2 \mathbf{b}$ had detectable cytotoxic activity on HUVEC with $\mathrm{IC}_{50}$ values exceeding $200 \mu \mathrm{M}$. This type of $\mathrm{Pt}(\mathrm{Iv})$ complexes was more selective to tumor cells compared with HUVEC. Consequently, both complexes $\mathbf{1 a}$ and $\mathbf{1 b}$ were promising anticancer candidates for further research.

\subsection{Cellular uptake}

Given that complexes 1a and $\mathbf{1 b}$ exhibited better cytotoxicity, they were chosen to conduct a cellular uptake test on HepG-2 and NCI-H460 cells by using ICP-MS. As for HepG-2 cell line, platinum accumulation of $\mathbf{1 b}$ was 1.28 times more potent than that of cisplatin. Meanwhile, the intracellular Pt levels of 1a and 1b were higher than that of cisplatin due to the lipophilicity, while complex 1a had the same Pt content as 1b in HepG-2 cells. Interestingly, the uptake of complex $\mathbf{1 b}$ by NCI-H460 cells was 2.32 times higher than that of $\mathbf{1 a}$.

According to Tables 1 and 3, it seems that enhanced cellular uptake is associated with increased cytotoxicity of complexes. However, the intracellular platinum level is not the only factor

Table 2 In vitro cytotoxicity of complexes $1 a-2 b$, cisplatin and oxaliplatin

\begin{tabular}{lrrl}
\hline & \multicolumn{3}{c}{$\mathrm{IC}_{50}{ }^{a}(\mu \mathrm{M})$} \\
\cline { 2 - 4 } Complex & \multicolumn{1}{c}{ SGC7901 $^{b}$} & \multicolumn{1}{c}{ SGC7901/CDDP $^{c}$} & \multicolumn{1}{c}{ HUVEC $^{d}$} \\
\hline Cisplatin & $9.96 \pm 0.87$ & $35.65 \pm 2.55$ & $36.92 \pm 2.23$ \\
Oxaliplatin & $13.47 \pm 1.55$ & $99.44 \pm 5.23$ & $51.03 \pm 4.42$ \\
1a & $16.79 \pm 1.45$ & $92.45 \pm 2.56$ & $59.11 \pm 2.54$ \\
1b & $16.76 \pm 1.78$ & $120.16 \pm 6.74$ & $56.47 \pm 1.65$ \\
2a & $20.15 \pm 1.44$ & $92.65 \pm 1.56$ & $>200$ \\
2b & $8.73 \pm 1.87$ & $97.50 \pm 3.67$ & $>200$
\end{tabular}

${ }^{a} \mathrm{IC}_{50}$ is the drug concentration effective in inhibiting $50 \%$ of the cell growth measured by the MTT assay after $48 \mathrm{~h}$ drug exposure. ${ }^{b}$ SGC7901: gastric cancer cell line. ${ }^{c}$ SGC7901/CDDP: cisplatinresistant gastric cancer cell line. ${ }^{d}$ HUVEC: human umbilical vein endothelial cell line. 
Table 3 Cellular uptake of $1 \mathrm{a}$ and $1 \mathrm{~b}$ in HepG-2 and NCl-H460 cells after $12 \mathrm{~h}$ of incubation ${ }^{a}$

\begin{tabular}{llr}
\hline & \multicolumn{2}{c}{ Pt content ${ }^{b}$ (nanograms per $10^{6}$ cells) } \\
\cline { 2 - 3 } Complex & HepG-2 & NCI-H460 \\
\hline Cisplatin & $176 \pm 15$ & $189 \pm 20$ \\
Oxaliplatin & $188 \pm 12$ & $196 \pm 19$ \\
1a & $213 \pm 17$ & $106 \pm 17$ \\
1b & $227 \pm 26$ & $246 \pm 31$
\end{tabular}

${ }^{a}$ HepG-2 and HCI-H460 cells were treated with $20 \mu \mathrm{M}$ of cisplatin, oxaliplatin, complexes $\mathbf{1 a}$ and $\mathbf{1 b}$ for $12 \mathrm{~h} .{ }^{b}$ Results are expressed as the mean \pm SD for four independent experiments.

deciding the cytotoxicity of platinum complexes. In fact, many other factors also affect the cytotoxic activity of platinum complexes, such as the effective amounts of the compounds that finally act on DNA. Actually, we have already found similar results in previous studies. ${ }^{28-30}$

\subsection{Complex 1a and $1 \mathrm{~b}$ induced apoptotic cell death}

Since complexes 1a and $\mathbf{1 b}$ showed better cytotoxicity, they were selected to carry out the apoptotic study against HepG-2 cells by Annexin V-FITC/PI assay. HepG-2 cells were incubated with 50 $\mu \mathrm{M}$ of indicated complexes for 24 hours. The quadrants Q1-Q4 represented four different cancer cell states: necrotic cells, late apoptotic or necrotic cells, living cells and early apoptotic cells, respectively.
Table 4 Red-green fluorescence ratio of positive controls and target complexes $1 a$ and $1 b^{a}$

\begin{tabular}{ll}
\hline Complex & Ratio (FL2/FL1) \\
\hline Negative control & 5.42 \\
CCCP & 0.04 \\
DCA & 4.17 \\
Cisplatin & 0.54 \\
Carboplatin & 2.56 \\
Oxaliplatin & 0.94 \\
1a : DCA $(1: 1)$ & 0.59 \\
1b : DCA $(1: 1)$ & 0.80 \\
1a & 0.98 \\
1b & 0.86
\end{tabular}

${ }^{a}$ HepG-2 cells cultured in the presence of $30 \mu \mathrm{M}$ of cisplatin, carboplatin, oxaliplatin, complex 1a or $\mathbf{1 b}$ for 48 hours at $37^{\circ} \mathrm{C}(\mathrm{DMF}$ final concentration $<0.4 \%$ ). Then the cells were harvested by centrifugation and incubated with JC-1 solution for $30 \mathrm{~min}$. After briefly washing, the proportions of red and green fluorescence intensity were immediately detected and analyzed by flow cytometry $(\mathrm{Ex}=488 \mathrm{~nm} ; \mathrm{Em}=530 \mathrm{~nm})$.

As shown in Fig. 3, complexes 1a and 1b $(28.75 \%$ and $28.97 \%$ ) had nearly the same apoptotic rate as cisplatin (28.79\%) against HepG-2 cells while showing a higher apoptotic rate than oxaliplatin (21.74\%; Fig. 2). As for HepG-2 cell line, after treated with $\mathbf{1 b}$ for 24 hours, the early apoptotic rate rose strikingly from $2.14 \%$ to $24.97 \%$ and the late apoptotic rate was increased from $4.17 \%$ to $4.99 \%$. Similarly, the early apoptotic rate of HepG-2 cell for 1a surged from $2.14 \%$ to $21.61 \%$ and the
Control

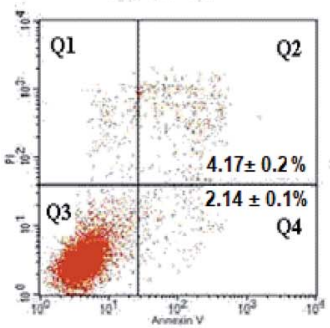

Cisplatin

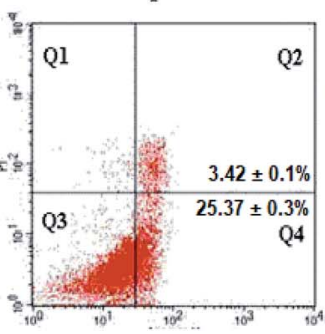

Oxaliplatin

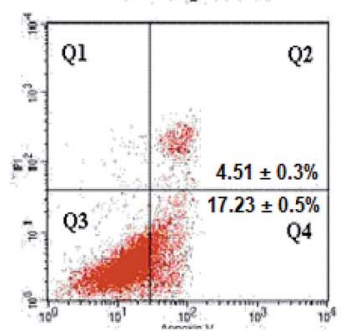

$1 \mathrm{a}$

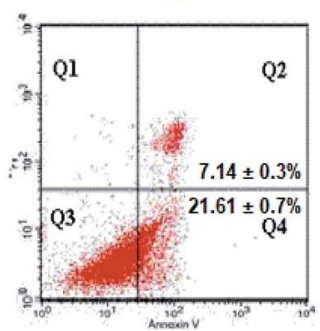

1b

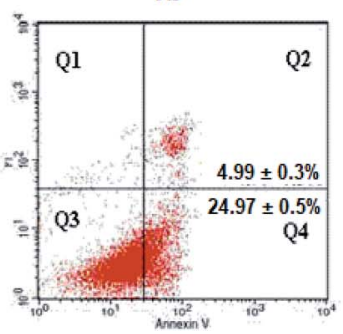

Fig. 3 Flow cytometric analysis of the distribution of HepG-2 cells treated with $50 \mu \mathrm{M}$ of cisplatin, oxaliplatin, complexes $1 \mathrm{a}$ and $1 \mathrm{~b}$ for 24 hours (DMF final concentration < $0.4 \%$ ). Cells were stained with $5 \mathrm{~mL}$ of Annexin V-FITC and incubated in the dark at $25^{\circ} \mathrm{C}$ for $10 \mathrm{~min}$. The fluorescence was measured by using a flow cytometer. The results were expressed as the percentage of normal and apoptotic cells at various stages by FCS Express software.
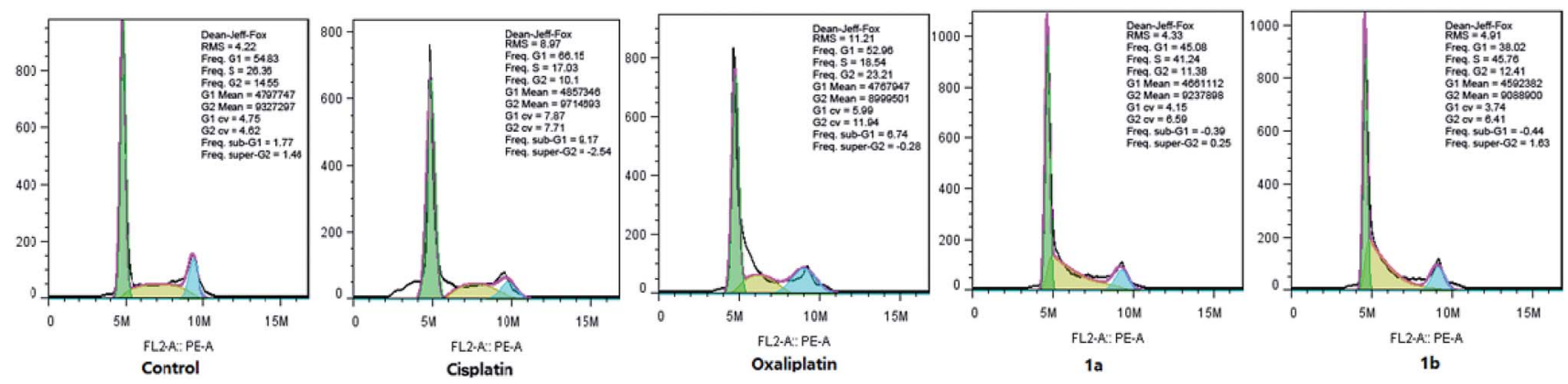

Fig. 4 Cell cycle distribution of HepG-2 cells cultured in the presence of $30 \mu \mathrm{M}$ of cisplatin, oxaliplatin, complexes $1 \mathrm{a}$ and $1 \mathrm{~b}$ (DMF final concentration < $0.4 \%$ ). The cells were seeded in 6 -well plates for 12 hours at $37^{\circ} \mathrm{C}$, and then were treated with cisplatin, oxaliplatin, complex $1 \mathrm{a}$ or 1b. After 12 hours of treatment, cells were harvested with trypsin and washed twice with PBS. 
Table 5 Molecular formulas and $[\mathrm{M}+\mathrm{Na}]^{+}$experimental and theoretical of $1 \mathrm{a}-2 \mathrm{~b}$

\begin{tabular}{|c|c|c|c|c|}
\hline & Molecular formula & {$[\mathrm{M}+\mathrm{Na}]^{+}$experimental } & {$[\mathrm{M}+\mathrm{Na}]^{+}$theoretical } & Error $[\mathrm{ppm}]$ \\
\hline 1a & $\mathrm{C}_{8} \mathrm{H}_{11} \mathrm{Cl}_{3} \mathrm{~N}_{2} \mathrm{O}_{7} \mathrm{Pt}$ & 569.9196 & 569.9172 & -4.0 \\
\hline $1 \mathbf{b}$ & $\mathrm{C}_{14} \mathrm{H}_{19} \mathrm{Cl}_{3} \mathrm{~N}_{2} \mathrm{O}_{7} \mathrm{Pt}$ & 649.9818 & 649.9798 & -2.9 \\
\hline $2 \mathbf{b}$ & $\mathrm{C}_{14} \mathrm{H}_{18} \mathrm{ClF}_{3} \mathrm{~N}_{2} \mathrm{O}_{7} \mathrm{Pt}$ & 636.0323 & 636.0295 & -4.2 \\
\hline
\end{tabular}

late apoptotic rate was increased from $4.17 \%$ to $7.14 \%$. Complex 1b showed a slightly higher population of apoptotic cells than complex 1a did. Based on the results from the cytotoxicity tests and the apoptotic assays, it was noted that there might be a positive correlation between these two assays. The order of apoptotic rates against HepG-2 cells from high to low was $\mathbf{1 b}$, 1a, cisplatin, and oxaliplatin. Complexes $\mathbf{1 a}$ and $\mathbf{1 b}$ were able to cause cancer cell death through apoptotic pathways.

\subsection{Effect on cell cycle arrest}

It is confirmed that cell cycle contains four different phases, including G1, G2, S, and $M$ stages. Pt(Iv) complexes could inhibit cancer cell growth by cell cycle arrest. As shown in Fig. 4, HepG-2 cells were treated with cisplatin, oxaliplatin, complex 1a or $\mathbf{1 b}$ for 12 hours, and the cell cycle distribution was examined by PI staining and following flow cytometry analysis.

The percentage of cells at G1 phase was increased significantly upon cisplatin treatment (from $54.83 \%$ to $66.15 \%$ ), while oxaliplatin arrested HepG-2 cells at G2 phase (from $14.55 \%$ to $23.21 \%$ ). Notably, the cell cycle arrest caused by complex $1 \mathbf{a}$ and 1b mainly occurred at $S$ phase (from $26.36 \%$ to $41.24 \%$ and from $26.36 \%$ to $45.76 \%$ ). Overall, it was confirmed that different from cisplatin and oxaliplatin, complex 1a and $\mathbf{1 b}$ induced cell cycle arrest at $S$ phase by inhibiting DNA replication in the nucleus. The different feature of cell cycle arrest is probably due to distinct DNA binding modes.

\subsection{Mitochondrial membrane potential}

Platinum(Iv) complexes $\mathbf{1 a}$ and $\mathbf{1 b}$ can release platinum(II) complexes and DCA under the intracellular reductive condition, targeting nuclear DNA and mitochondria, respectively. In addition, DCA can result in mitochondrial dysfunction, and the change of mitochondrial function is manifested as the decrease in membrane potential and stability. The change of transmembrane potential causes the release of cytochrome $\mathrm{C}$ and a variety of apoptosis inducing factors (AIFs), which activate a cascade of apoptosis and eventually lead to apoptosis. In order to confirm that the change of mitochondria membrane potential was caused by Pt(Iv) complexes, HepG-2 cells were incubated with the tested complexes for 48 hours and examined by JC- 1 staining method.

Complexes 1a and $\mathbf{1 b}$ were selected to test their effects on mitochondrial membrane potential with carbonylcyanide- $m$ chlorophenylhydrazone (CCCP), DCA, cisplatin, carboplatin and oxaliplatin as positive controls. As shown in Table 4, compared with the negative control, red-green fluorescence ratio of each group was dropped. In fact, complexes $\mathbf{1 a}$ and $\mathbf{1 b}$ notably reduced the mitochondrial membrane potential (FL2/ $\mathrm{FL} 1=0.98$ and FL2/FL1 $=0.86)$. However, the decrease caused by complexes $\mathbf{1 a}$ and $\mathbf{1 b}$ was less than that induced by 1a : DCA $(1: 1)$ and 1b : DCA $(1: 1)($ FL2/FL1 $=0.59$ and FL2/ FL1 $=0.80)$. The decline of mitochondrial membrane potential was a landmark event in the early stage of apoptosis, and the $\mathrm{IC}_{50}$ values of complexes $\mathbf{1 a}$ and $\mathbf{1 b}$ were lower than an equivalent mixture: DCA : A $(1: 1)$ and DCA : B (1:1). Besides, complexes $\mathbf{1 a}$ and $\mathbf{1 b}$ could release the corresponding platinum(II) and DCA by reduction, which could target mitochondria.

\section{Conclusions}

In this manuscript, we explored two types of $\mathrm{Pt}$ (Iv) complexes $\mathbf{1 a - 1 b}$ and $\mathbf{2 a - 2 b}$ by taking complexes $\mathbf{A}$ and $\mathbf{B}$ as the lead compounds, and investigated dual-threat platinum prodrugs and the lipophilicity of the TFA as the axial ligand, respectively. Complexes $\mathbf{1 a}$ and $\mathbf{1 b}$ could rapidly transform in PBS $(\mathrm{pH}=7.4)$ with the hydrolysis of the axial DCA ligands $\left(t_{1 / 2}=60 \mathrm{~min}\right)$. According to the $\mathrm{IC}_{50}$ values, $\mathbf{1 a}$ and $\mathbf{1} \mathbf{b}$ had better cytotoxic activity than cisplatin, oxaliplatin and carboplatin against HepG-2 and MCF-7 cell lines. Since Pt(Iv) prodrugs 1a-2b had relatively kinetic inertia, they possessed less toxicity than cisplatin and oxaliplatin against HUVEC cell line. In addition, it was confirmed that complexes $\mathbf{1 a}$ and $\mathbf{1 b}$ induced cell cycle arrest at $S$ phase $(41.24 \%$ and $45.76 \%)$ by inhibiting DNA replication in the nucleus. Moreover, both of them significantly reduced the mitochondrial membrane potential. Above all, platinum(Iv) prodrugs could improve the anticancer activity using a dual-targeting strategy with dichloroacetate axial ligand, which released platinum(II) complexes and DCA under the intracellular reductive condition, targeting nuclear DNA and mitochondria, respectively.

Furthermore, a series of novel platinum complexes with ethylenediamine- $N, N^{\prime}$-di-2/3-propionate ester as ligands has been reported to induce caspase-dependent apoptosis. ${ }^{31}$ Therefore, it is still a reasonable way to design antitumor platinum complexes targeting nuclear DNA and mitochondria. It may be an interesting approach to combine such complexes with drug delivery systems in the future.

\section{Experimental}

\subsection{Chemistry}

Materials and methods. All reagents and solvents were of analytical grade and were used without further purification. Complexes A and $\mathbf{B}$ were prepared as described in our previous 
study. ${ }^{19}$ All tumor cell lines were purchased from Hangzhou Hibio bioTech company. ${ }^{1} \mathrm{H}$ NMR and ${ }^{13} \mathrm{C}$ NMR spectra were recorded in DMSO- $d_{6}$ on a Bruker $300 \mathrm{MHz}$ or $500 \mathrm{MHz}$ spectrometer. Platinum contents were determined by an inductively coupled plasma-mass spectrometer (ICP-MS, Optima 5300DV, PerkinElmer, USA). Mass spectra were measured on an Agilent 6224 ESI/TOF MS instrument.

Dichloroacetatodiamminechlorido(3-oxo-1,1-cyclobutanedicarboxylato)platinum(Iv) (1a). Complex A (0.38 g, $1.00 \mathrm{mmol}$ ), dichloroacetic acid $(3 \mathrm{~mL})$ and acetone $(50 \mathrm{~mL})$ were added into a $100 \mathrm{~mL}$ reaction bottle. The acetone solution $(10 \mathrm{~mL})$ of $N$ chlorobutanedimide $(0.14 \mathrm{~g}, 1.05 \mathrm{mmol})$ was then added into the reaction system slowly, which was reacted at $25{ }^{\circ} \mathrm{C}$ for 12 hours. Then the organic phase was evaporated under reduced pressure, obtaining the viscous light yellow compound 1a. Furthermore, complex 1a was precipitated out by adding diethyl ether $(150 \mathrm{~mL})$, which was washed with a small amount of ethanol several times and dried in vacuo. White solid, yield: $0.36 \mathrm{~g}$ (67\%). IR (KBr, cm $\left.{ }^{-1}\right): 3168 \mathrm{~m}, 3064 \mathrm{~m}, 2924 \mathrm{~m}, 2870 \mathrm{~m}$, $1791 \mathrm{~m}, 1625 \mathrm{~s}, 1371 \mathrm{~m}, 1025 \mathrm{~m} ;{ }^{1} \mathrm{H}$ NMR (300 MHz, $d_{6}$-DMSO): $\delta 3.50\left(\mathrm{~s}, 2 \mathrm{H}, \mathrm{CH}_{2}\right.$ of cyclobutane), $3.57\left(\mathrm{~s}, 2 \mathrm{H}, \mathrm{CH}_{2}\right.$ of cyclobutane), 6.01-6.44 (m, 6H, $\left.2 \times \mathrm{NH}_{3}\right), 6.52\left(\mathrm{~s}, 1 \mathrm{H}, \mathrm{CHCl}_{2}\right) ;{ }^{13} \mathrm{C}$ NMR (75 MHz, $d_{6}$-DMSO): 204.0, 176.1, 169.2, 67.1, 60.2, 59.8, 46.0; HR-MS (m/z) (ESI): calcd for $\mathrm{C}_{8} \mathrm{H}_{11} \mathrm{Cl}_{3} \mathrm{~N}_{2} \mathrm{NaO}_{7} \mathrm{Pt}[\mathrm{M}+\mathrm{Na}]^{+}$, 569.9172; found, 569.9196. Elemental analysis calcd (\%) for $\mathrm{C}_{8} \mathrm{H}_{11} \mathrm{Cl}_{3} \mathrm{~N}_{2} \mathrm{O}_{7} \mathrm{Pt}: \mathrm{C}, 17.51 ; \mathrm{H}, 2.02 ; \mathrm{N}, 5.11$; found: C, 17.47; H, 2.14; N, 5.13 .

Dichloroacetato(cyclohexane-1R,2R-diamine)chlorido(3-oxo1,1-cyclobutanedicarboxylato)platinum(Iv) (1b). Complex B $(0.47 \mathrm{~g}, 1.00 \mathrm{mmol})$, dichloroacetic acid (3 mL) and acetone (50 $\mathrm{mL}$ ) were added into a $100 \mathrm{~mL}$ reaction bottle. The acetone solution $(10 \mathrm{~mL})$ of $N$-chlorobutanedimide $(0.14 \mathrm{~g}, 1.05 \mathrm{mmol})$ was then added into the reaction system slowly, which was reaction reacted at $25^{\circ} \mathrm{C}$ for 18 hours. After the reaction, organic phase was evaporated under reduced pressure, obtaining the viscous light yellow compound 1b. Furthermore, complex $\mathbf{1 b}$ was precipitated out by adding diethyl ether $(150 \mathrm{~mL})$. Complex 1b was washed with a small amount of ethanol several times and dried in vacuo. White solid, yield: $0.27 \mathrm{~g}$ (52\%). IR $\left(\mathrm{KBr}, \mathrm{cm}^{-1}\right): 3170 \mathrm{~m}, 3061 \mathrm{~m}, 2936 \mathrm{~m}, 2872 \mathrm{~m}, 1793 \mathrm{~m}, 1626 \mathrm{~s}$, $1370 \mathrm{~m}, 1027 \mathrm{~m}$; ${ }^{1} \mathrm{H}$ NMR (300 MHz, $d_{6}$-DMSO): $\delta 1.00-1.14(\mathrm{~m}$, $2 \mathrm{H}, \mathrm{CH}_{2}$ of DACH), 1.38-1.57 (m, $4 \mathrm{H}, 2 \times \mathrm{CH}_{2}$ of DACH), 1.97$2.09\left(\mathrm{~m}, 2 \mathrm{H}, \mathrm{CH}_{2}\right.$ of $\left.\mathrm{DACH}\right), 2.58-2.66\left(\mathrm{~m}, 2 \mathrm{H}, 2 \times \mathrm{CHNH}_{2}\right), 3.14$ (m, $2 \mathrm{H}, \mathrm{CH}_{2}$ of cyclobutane), 3.61 (s, $2 \mathrm{H}, \mathrm{CH}_{2}$ of cyclobutane), $6.49\left(\mathrm{~s}, 1 \mathrm{H}, \mathrm{CHCl}_{2}\right), 7.51-8.26\left(\mathrm{~m}, 4 \mathrm{H}, 2 \times \mathrm{NH}_{2}\right) ;{ }^{13} \mathrm{C} \mathrm{NMR}(75$ MHz, $d_{6}$-DMSO): 203.6, 176.6, 168.4, 67.7, 62.4, 61.4, 61.1, 58.6, 46.4, 31.3, 30.8, 24.0, 23.9; HR-MS ( $\mathrm{m} / \mathrm{z}$ ) (ESI): calcd for $\mathrm{C}_{14^{-}}$ $\mathrm{H}_{19} \mathrm{Cl}_{3} \mathrm{~N}_{2} \mathrm{NaO}_{7} \mathrm{Pt}[\mathrm{M}+\mathrm{Na}]^{+}$, 649.9798; found, 649.9818; elemental analysis calcd (\%) for $\mathrm{C}_{14} \mathrm{H}_{19} \mathrm{Cl}_{3} \mathrm{~N}_{2} \mathrm{O}_{7} \mathrm{Pt}$ : C, 26.74; $\mathrm{H}$, 3.05 ; N, 4.46; found: C, 26.83; H, 3.11; N, 4.38.

Trifluoroacetatodiamminechlorido(3-oxo-1,1-cyclobutanedicarboxy-lato)platinum(Iv) (2a). Complex A (0.38 g, $1.00 \mathrm{mmol})$, trifluoroacetic acid $(3 \mathrm{~mL})$ and acetone $(50 \mathrm{~mL})$ were added into a $100 \mathrm{~mL}$ reaction bottle. The acetone solution $(10 \mathrm{~mL})$ of $N$ chlorobutanedimide $(0.14 \mathrm{~g}, 1.05 \mathrm{mmol})$ was then added into the reaction system slowly, which was reaction reacted at $25{ }^{\circ} \mathrm{C}$ for 12 hours. After the reaction, organic phase was evaporated under reduced pressure, obtaining the viscous light yellow compound 2a. Furthermore, complex 2a was precipitated out by adding diethyl ether $(150 \mathrm{~mL})$. Complex $2 \mathrm{a}$ was washed with a small amount of ethanol several times and dried in vacuo. White solid, yield: $0.39 \mathrm{~g}(63 \%)$. IR ( $\left.\mathrm{KBr}, \mathrm{cm}^{-1}\right): 3574 \mathrm{~m}, 3247 \mathrm{~m}$, $3103 \mathrm{~m}, 1783 \mathrm{~m}, 1668 \mathrm{~m}, 1360 \mathrm{~m}, 1207 \mathrm{~m}, 1123 \mathrm{~m} ;{ }^{1} \mathrm{H}$ NMR $(300$ $\mathrm{MHz}, d_{6}$-DMSO): $\delta 3.48$ (s, 2H, $\mathrm{CH}_{2}$ of cyclobutane), $3.51(\mathrm{~s}, 2 \mathrm{H}$, $\mathrm{CH}_{2}$ of cyclobutane), 6.20-6.58 (m, 6H, $\left.2 \times \mathrm{NH}_{3}\right) ;{ }^{13} \mathrm{C} \mathrm{NMR}(75$ MHz, $d_{6}$-DMSO): 203.3, 176.1, 166.3, 60.0, 59.8, 46.1; HR-MS ( $m /$ z) (ESI): calcd for $\mathrm{C}_{8} \mathrm{H}_{10} \mathrm{ClF}_{3} \mathrm{~N}_{2} \mathrm{NaO}_{7} \mathrm{Pt}[\mathrm{M}+\mathrm{Na}]^{+}$, 555.9669; found, 555.9687; elemental analysis calcd (\%) for $\mathrm{C}_{8} \mathrm{H}_{10} \mathrm{ClF}_{3^{-}}$ $\mathrm{N}_{2} \mathrm{O}_{7}$ Pt: C, $18.00 ; \mathrm{H}, 1.89 ; \mathrm{N}, 5.25$; found: C, 18.06; H, 1.84; N, 5.27 .

Trifluoroacetato(cyclohexane-1R,2R-diamine)chlorido(3-oxo1,1-cyclobutanedicarboxylato)platinum(Iv) (2b). Complex B $(0.47 \mathrm{~g}, 1.00 \mathrm{mmol})$, trifluoroacetic acid $(3 \mathrm{~mL})$ and acetone (50 $\mathrm{mL}$ ) were added into a $100 \mathrm{~mL}$ reaction bottle. The acetone solution $(10 \mathrm{~mL})$ of $N$-chlorobutanedimide $(0.14 \mathrm{~g}, 1.05 \mathrm{mmol})$ was then added into the reaction system slowly, which was reaction reacted at $25^{\circ} \mathrm{C}$ for 18 hours. After the reaction, organic phase was evaporated under reduced pressure, obtaining the viscous light yellow compound $\mathbf{2 b}$. Furthermore, complex $\mathbf{2 b}$ was precipitated out by adding diethyl ether $(150 \mathrm{~mL})$. Complex $2 \mathbf{b}$ was washed with a small amount of ethanol several times and dried in vacuo. White solid, yield: $0.35 \mathrm{~g}(57 \%)$. IR (KBr, $\left.\mathrm{cm}^{-1}\right)$ : $3561 \mathrm{~m}, 3468 \mathrm{~m}, 2939 \mathrm{~m}, 1796 \mathrm{~m}, 1719 \mathrm{~m}, 1633 \mathrm{~m}, 1370 \mathrm{~m}, 1178 \mathrm{~m}$; ${ }^{1} \mathrm{H}$ NMR (300 MHz, $d_{6}$-DMSO): $\delta 0.99-1.13\left(\mathrm{~m}, 2 \mathrm{H}, \mathrm{CH}_{2}\right.$ of DACH), 1.48-1.52 (m, 4H, $\mathrm{CH}_{2}$ of $\left.\mathrm{DACH}\right), 1.96-2.08\left(\mathrm{~m}, 2 \mathrm{H}, \mathrm{CH}_{2}\right.$ of $\mathrm{DACH}), 2.60-2.62\left(\mathrm{~m}, 2 \mathrm{H}, 2 \times \mathrm{CHNH}_{2}\right), 3.29\left(\mathrm{~s}, 2 \mathrm{H}, \mathrm{CH}_{2}\right.$ of cyclobutane), 3.63 (s, $2 \mathrm{H}, \mathrm{CH}_{2}$ of cyclobutane), 7.63-8.37 (m, $4 \mathrm{H}$, $\left.2 \times \mathrm{NH}_{2}\right) ;{ }^{13} \mathrm{C}$ NMR (75 MHz, $d_{6}$-DMSO): 203.6, 176.7, 176.6, 62.6, 61.3, 61.2, 58.3, 46.5, 31.1, 30.7, 24.0, 23.9; HR-MS ( $\mathrm{m} / \mathrm{z}$ ) (ESI): calcd for $\mathrm{C}_{14} \mathrm{H}_{18} \mathrm{ClF}_{3} \mathrm{~N}_{2} \mathrm{NaO}_{7} \mathrm{Pt}[\mathrm{M}+\mathrm{Na}]^{+}$, 636.0295; found, 636.0323; elemental analysis calcd (\%) for $\mathrm{C}_{14} \mathrm{H}_{18} \mathrm{ClF}_{3} \mathrm{~N}_{2} \mathrm{O}_{7} \mathrm{Pt}$ : C, 27.39; H, 2.96; N, 4.56; found: C, 27.36; H, 2.84; N, 4.63 (Table 5).

Stability of 1a-2b in PBS. The solution behavior of $\mathbf{1 a}$ and $\mathbf{1 b}$ were investigated by ${ }^{1} \mathrm{H}$ NMR spectroscopy. Complexes $\mathbf{1 a}$ and 1b $(0.786 \mu \mathrm{mol})$ was dissolved in DMSO- $d_{6}(0.5 \mathrm{~mL}) .100 \mu \mathrm{L}$ of the previous solution was diluted with $900 \mu \mathrm{L}$ of a deuterated aqueous phosphate buffered solution (PBS $7.87 \mathrm{mM}, \mathrm{pH} 7.4$; at $37{ }^{\circ} \mathrm{C}$ ) obtaining a final solution (DMSO- $d_{6} / \mathrm{D}_{2} \mathrm{O}, 10: 90(\mathrm{v} / \mathrm{v})$ ). ${ }^{1} \mathrm{H}$ NMR spectra recorded at different time intervals.

Complexes $2 \mathbf{a}$ and $\mathbf{2 b}(0.786 \mu \mathrm{mol})$ were dissolved in $\mathrm{MeOH}$ $(1 \mathrm{~mL})$. The stability of $\mathbf{2 a}$ and $2 \mathbf{b}$ in a $\mathrm{MeOH} / \mathrm{PBS}(1: 9)$ was investigated by HPLC (PBS $7.87 \mathrm{mM}, \mathrm{pH} 7.4$; at $37{ }^{\circ} \mathrm{C}$ ). HPLC recorded at different time intervals. Reversed phase HPLC was implemented on a $250 \times 4.6 \mathrm{~mm}$ ODS column and the HPLC profiles were recorded on UV detection at $226 \mathrm{~nm}$. Mobile phase consisted of $\mathrm{MeCN}: \mathrm{H}_{2} \mathrm{O}=25: 75(\mathrm{v} / \mathrm{v})$, and flow rate was 1.0 $\mathrm{mL} \min ^{-1}$. The samples were taken for HPLC analysis after filtration by $0.5 \mu \mathrm{m}$ filter.

\subsection{Bioactivity study}

Cell culture. All adherent cell lines, including human gastric cancer cell line (BGC803), human hepatocellular carcinoma cell line (HepG-2), human breast carcinoma cell line (MCF-7), large 
cell lung cancer cell line NCI-H460, gastric cancer cell line (SGC7901), cisplatin-resistant gastric cancer cell line (SGC7901/ CDDP), and human umbilical vein endothelial cell line (HUVEC) were cultured in a humidified, 5\% $\mathrm{CO}_{2}$ atmosphere at $37{ }^{\circ} \mathrm{C}$ and kept in monolayer culture in DMEM medium supplemented with $10 \%$ fetal bovine serum (FBS), $100 \mathrm{mg} \mathrm{mL}^{-1}$ of streptomycin and $100 \mathrm{mg} \mathrm{mL} \mathrm{m}^{-1}$ of penicillin. All cell lines used in this study were obtained form KeyGen biotech company.

MTT assay. The cells were seeded in 96-well tissue cultured plates at a density of $5 \times 10^{3}$ cells per well. After overnight incubation, the cells were treated with the diluted solution of complexes, which were obtained by dissolving in DMF and diluting with culture medium (DMF final concentration < $0.4 \%)$. After 48 hours of incubation at $37^{\circ} \mathrm{C}, 10 \mu \mathrm{L}$ of a freshly diluted 3-(4,5-dimethyl-2-thiazolyl)-2,5-diphenyl-2 $H$-tetrazolium bromide (MTT) solution ( $5 \mathrm{mg} \mathrm{mL}{ }^{-1}$ ) were added to each well and the plate was incubated at $37{ }^{\circ} \mathrm{C}$ in a humidified $5 \% \mathrm{CO}_{2}$ atmosphere for 4 hours. At the end of the incubation period, the medium was removed and the formazan product was dissolved in $150 \mu \mathrm{L}$ of DMSO. The cell viability was evaluated by measurement of the absorbance at $570 \mathrm{~nm}$, using an absorbance reader (Bio-Rad). IC $_{50}$ values were calculated from curves constructed by plotting cell survival inhibitory rate (\%) versus drug concentration logarithm. The reading values were converted to the percentage of control (\% cell survival). Finally, cytotoxic effects were expressed as $\mathrm{IC}_{50}$ values.

Cellular uptake test. HepG-2 and NCI-H460 cells were seeded in 6-well plates. After the cells reached about $80 \%$ confluence, $20 \mu \mathrm{M}$ of cisplatin, oxaliplatin, $\mathbf{1 a}$ and $\mathbf{1 b}$ were added, respectively. After 12 hours incubation, cells were collected and washed 3 times with ice-cold PBS then centrifuged at $1000 \mathrm{~g}$ for $10 \mathrm{~min}$ and resuspended in $1 \mathrm{~mL}$ of PBS. A volume of $100 \mu \mathrm{L}$ was taken out to determine the cell density. The rest of the cells was spun down and digested at $65{ }^{\circ} \mathrm{C}$ in $200 \mu \mathrm{L}$ of $65 \% \mathrm{HNO}_{3}$ for 10 hours. The content of Pt level in cells was obtained by ICP-MS.

Cell apoptosis study by flow cytometry. Apoptosis induced by platinum complexes was tested by flow cytometry using an Annexin V-FITC apoptosis detection kit according to the manufacturer's instructions. Flow cytometric analysis of the distribution of HepG-2 cells treated with cisplatin, oxaliplatin, complex 1a and $1 \mathrm{~b}$ at $50 \mu \mathrm{M}$ for 24 hours, and cells were collected by centrifugation ( $\left.5 \mathrm{~min}, 25{ }^{\circ} \mathrm{C}, 2000 \mathrm{rpm}\right)$. The cells were then washed twice with cold water and resuspended in Annexin V-FITC binding buffer (0.1 M Hepes/NaOH ( $\mathrm{pH} 7.4)$, $1.4 \mathrm{M} \mathrm{NaCl}, 25 \mathrm{mM} \mathrm{CaCl}_{2}$ ) at a concentration of $1 \times 10^{6}$ cells $\mathrm{mL}^{-1}$. Cells were stained with $5 \mathrm{~mL}$ of Annexin V-FITC and incubated in the dark at $25{ }^{\circ} \mathrm{C}$ for $10 \mathrm{~min}$. The cell suspension was centrifuged for $5 \mathrm{~min}\left(25^{\circ} \mathrm{C}, 2000 \mathrm{rpm}\right)$, and cells were resuspended in Annexin V-FITC binding buffer. Propidium iodide $(10 \mathrm{~mL})$ was added, and the tubes were placed on ice, away from light. The fluorescence was measured by using a flow cytometer (FACScan, Becton Dickson, USA). The results were expressed as the percentage of normal and apoptotic cells at various stages by FCS Express software.

Effect on cell cycle arrest. HepG- 2 cells with a large amount of $1 \times 10^{6}$ were inoculated in 6-well plate and incubated at $37^{\circ} \mathrm{C}$ in $5 \% \mathrm{CO}_{2}$ overnight. Cisplatin, oxaliplatin, complex $\mathbf{1 a}$ and $\mathbf{1 b}$ at the dose of $30 \mu \mathrm{M}$ were treated with the cells for 12 hours respectively, and then cells were harvested with trypsin and washed twice with PBS. Moreover, cells were fixed in cold 70\% ethanol and stored at $4{ }^{\circ} \mathrm{C}$ for 24 hours. After washing in PBS, cells were treated with RNase $\left(75 \mathrm{kU} \mathrm{mL}^{-1}\right)$ for $30 \mathrm{~min}$ at $37^{\circ} \mathrm{C}$. Propidium iodide was finally added to stain cells and fluorescence intensity was monitored by a flow cytometer. Finally, $1 \times$ $10^{4}$ cells were acquired for each analysis.

Mitochondrial membrane potential. JC-1 (Beyotime, China), as a lipophilic cationic dye, was used to monitor the level of MMP in the cells. At normal state, the MMP is high and JC-1 appears as aggregates showing red fluorescence. However, when apoptosis occurs, the MMP reduced and JC-1 displayed as monomers, which is indicated by green fluorescence. In order to confirm that the change of mitochondria membrane potential was caused by the $\mathrm{Pt}(\mathrm{Iv})$ complexes, the tested complexes were incubated with HepG-2 for 48 hours by JC-1 staining method. For flow cytometry analysis, HepG-2 cells were plated in 6-well plates $\left(3 \times 10^{5}\right.$ cells per well) and grown for 24 hours, and treated with complexes $\mathbf{1 a}$ and $\mathbf{1 b}$ at the indicated concentrations for 48 hours. Then the cells were harvested by centrifugation and incubated with JC-1 solution for $30 \mathrm{~min}$. After briefly washing, the proportions of red and green fluorescence intensity were immediately detected and analysed by flow cytometry $(\mathrm{Ex}=488 \mathrm{~nm} ; \mathrm{Em}=530 \mathrm{~nm})$.

\section{Conflicts of interest}

The authors declare no competing financial interest.

\section{Acknowledgements}

We are grateful to the China Postdoctoral Science Foundation (no. 2016M600473), the Postdoctoral Science Foundation of Zhejiang Province (no. zj20160107), and the National Natural Science Foundation of China (Project 21808205) for financial aids to this work. We are grateful to the Zhejiang Provincial Key R\&D Project (No. 2018C03074). We thank the Jiangsu Province Hi-Tech Key Laboratory for Biomedical Research at Southeast University for completing the in vitro tests.

\section{Notes and references}

1 D. M. Cheff and M. D. Hall, J. Med. Chem., 2017, 60, 45174532.

2 N. J. Wheate, S. Walker, G. E. Craig and R. Oun, Dalton Trans., 2010, 39, 8113-8127.

3 J. D. White, M. F. Osborn, A. D. Moghaddam, L. E. Guzman, M. M. Haley and V. J. DeRose, J. Am. Chem. Soc., 2013, 135, 11680-11683.

4 R. A. Hazlitt, J. Min and J. Zuo, J. Med. Chem., 2018, 61, 55125524.

5 R. Qun, Y. E. Moussa and N. J. Wheate, Dalton Trans., 2018, 47, 6645-6653.

6 E. Martinez-Balibrea, A. Martinez-Cardus, A. Gines, V. R. Porras, C. Moutinbo, L. Layos, J. L. Manzano, 
C. Buges, S. Bystrup, M. Esteller and A. Abad, Mol. Cancer Ther., 2015, 14, 1767-1776.

7 X. Y. Wang, X. H. Wang and Z. J. Guo, Acc. Chem. Res., 2015, 48, 2622-2631.

8 M. Yang, H. Z. Wu, J. L. Chu, L. A. Gabriel, K. S. Anderson, C. M. Furdui and U. Bierbach, Chem. Commun., 2018, 54, 7479-7482.

9 A. Abu Ammar, R. Raveendran, D. Gibson, T. Nassar and S. Benita, J. Med. Chem., 2016, 59, 9035-9046.

10 N. Wang, Z. G. Wang, Z. F. Xu, X. F. Chen and G. Y. Zhu, Angew. Chem., Int. Ed., 2018, 57, 3426-3430.

11 D. Y. Q. Wong, J. Y. Lau and W. H. Ang, Dalton Trans., 2012, 41, 6104-6111.

12 K. Mitra, C. E. Lyons and M. C. T. Hartman, Angew. Chem., Int. Ed., 2018, 57, 10263-10267.

13 G. De Lima Lopes, Y. L. Wu, S. Sadowski, J. Zhang, R. Rangwala, D. Kush and T. Mok, J. Thorac. Oncol., 2016, 11, S244-S245.

14 C. A. Garcia, S. Dacic and L. C. Villaruz, J. Thorac. Oncol., 2018, 13, e135-e136.

15 Z. Z. Zhu, Z. H. Wang, C. L. Zhang, Y. J. Wang, H. M. Zhang, Z. J. Gan and Z. J. Guo, Chem. Sci., 2019, 10, 3089-3095.

16 F. F. Chen, G. Xu, X. D. Qin, X. F. Jin and S. H. Gou, J. Pharmacol. Exp. Ther., 2017, 263, 221-239.

17 E. Gabano, M. Ravera, E. Perin, I. Zanellato, B. Rangone, M. J. McGlinchey and D. Osella, Dalton Trans., 2019, 48, 435-445.

18 X. Y. Yao, C. M. Tracy and U. Bierbach, Inorg. Chem., 2019, 58, 43-46.

19 J. Zhao, S. H. Gou and F. F. Liu, Chem.-Eur. J., 2014, 20, 15216-15225.
20 F. H. Chen, X. F. Jing, J. Zhao and S. H. Gou, Exp. Cell Res., 2018, 364, 68-83.

21 E. D. Michelakis, L. Webster and J. R. Mackey, Cancer, 2008, 99, 989-994.

22 S. Dhar and S. J. Lippard, Proc. Natl. Acad. Sci. U. S. A., 2009, 106, 22199-22204.

23 W. P. Liu, J. Su, J. Jiang, X. Y. Li, Q. S. Ye, H. Y. Zhou, J. L. Chen and Y. Li, Sci. Rep., 2013, 3, 2464.

24 S. Savino, V. Gandin, J. D. Hoeschele, C. Marzano, G. Natile and N. Margiotta, Dalton Trans., 2018, 47, 7144-7158.

25 N. Margiotta, P. Papadia, F. Lazzaro, M. Crucianelli, F. De Angelis, C. Pisano, L. Vesci and G. Natile, J. Med. Chem., 2005, 48, 7821-7828.

26 J. J. Wilson and S. J. Lippard, J. Med. Chem., 2012, 55, 53265336.

27 E. Wexselblatt, R. Raveendran, S. Salameh, A. FriedmanEzra, E. Yavin and D. Gibson, Chem.-Eur. J., 2015, 21, 3108-3114.

28 F. F. Liu, S. H. Gou, F. H. Chen, L. Fang and J. Zhao, J. Med. Chem., 2015, 58, 6368-6377.

29 X. C. Huang, R. Z. Huang, S. H. Gou, Z. M. Wang, Z. X. Liao and H. S. Wang, Bioconjugate Chem., 2016, 27, 2132-2148.

30 J. Pracharova, T. Saltarella, T. R. Radosova Muchova, S. Scintilla, V. Novohradsky, O. Novakova, F. P. Intini, C. Pacifico, G. Natile, P. Ilik, V. Brabec and J. Kasparkova, J. Med. Chem., 2015, 58, 847-859.

31 G. N. Kaluderović, S. A. Mijatović, B. B. Zmejkovski, M. Z. Bulatović, S. Gómez-Ruiz, M. K. Mojić, D. Steinborn, D. M. Miljković, H. Schmidt, S. D. Stošić-Grujičić, T. J. Saboe and D. D. Maksimović-Ivanić, Metallomics, 2012, 4, 979-987. 